\section{Silicon philanthropists follow a great tradition}

Sir - What is being called 'venture philanthropy' in your News feature 'Biomedical philanthropy, Silicon Valley style' (Nature $410,140-143 ; 2001)$ is hardly a new concept - it is an example of what has traditionally characterized 'thoughtful philanthropy'. In fact, it is very like the 'old' strategic philanthropy envisioned and practised by many private foundations established at the beginning of the twentieth century.

Robert Kohler's book Partners in Science (Univ. Chicago Press, 1991) provides many examples of the essential role private funders played in the development of modern molecular biology, genetics, public health and other biomedical research fields. The Silicon Valley entrepreneurs interviewed in your feature are following a tradition long established by private funders who viewed their money as providing venture capital for the common good and who long held the view that philanthropy should invest in the acquisition of new knowledge and in its responsible application. Further, the staff of the new foundations are following in the footsteps of a profession first defined by the Rockefeller Foundation 'circuit riders' - programme officers knowledgeable in their fields, actively seeking out promising research projects needing support.

I do not intend to detract from the laudable efforts of these new philanthropists to pursue thoughtful giving that takes risks and invests in new ideas with a minimum of hassle and red tape. But I do not see why they need to be flattered into thinking they are inventing something new - or that, as some of them seem to believe, they have a new model that needs to be emulated by all funders. Just as there is a certain dishonesty in the communication between researchers and government funders (the 'proposal' describing work already completed), there is a growing risk of dishonest dialogue between scientists and some of the philanthropists identified by the anecdotes Trisha Gura relates ('No one but you has the keen insight to recognize my brilliant idea').

The number of projects and researchers supported by private philanthropy will remain small compared with those receiving government support, and private funding relies on its partnership with public dollars. Peer review may not be perfect, but neither is investing in whoever grabs someone's attention or ear.

The true richness of private philanthropy is found in its diversity of approaches and its distributed decisionmaking processes that allow many different points of view - and many different grantmaking approaches — to flourish. Susan M. Fitzpatrick

James S. McDonnell Foundation, 1034 South Brentwood Boulevard, Suite 1850, St Louis, Missouri 63110, USA

\section{When DNA research menaces diversity}

Sir - The Nature Science Update "Synthetic viruses just around the corner" reported a discussion about scientists' imminent ability to synthesize new viruses for producing better vaccines or for devising deadlier biological weapons. I would like to give an example where genetic engineering of viruses can undermine careful management of natural resources.

Two new rabbit virus strains are being developed for opposing reasons. On the one hand, a group in Australia is modifying rabbit myxoma virus to transmit reproductive sterility and so reduce numbers in a region where rabbits constitute a pest ${ }^{2}$. On the other, a European group is modifying myxoma virus to express rabbit haemorrhagic disease virus capsid protein $^{3}$ to protect rabbits against both diseases and encourage the recovery of wild populations within the species' original distribution area.

Each goal is logical within its regional context. However, the history of rabbit viruses shows that outcomes can conflict with initial goals. First recorded in Montevideo in 1896, myxoma virus was successfully released in Australia in 1950 to control rabbit populations, but an illegal release in 1952 in France led to the virus spreading throughout Europe. Similarly, rabbit haemorrhagic disease, which spread naturally from Chinese rabbitries throughout Europe in 1987, spread in Australia after an accidental release from a trial island and in New Zealand after an illegal release in 1997.

The new modified viruses could spread worldwide as easily as myxomatosis and rabbit haemorrhagic disease initially spread. The establishment of modified myxoma virus into inappropriate regions could have disastrous effects on biodiversity. The preservation of Australasian ecosystems, as well as the conservation of endangered predators in Europe, depends on the same species: the wild rabbit, the target of both modified viruses.

It is therefore essential that modified viruses are very carefully and appropriately used. Biotechnology policies on the release of modified organisms rely on national authorities. But rabbits are distributed throughout the world, so it is essential to guide the development, release and regulation of rabbit virus biotechnology, and to enforce international controls to prevent accidental spread of genetically modified viruses.

Elena Angulo

Instituto de Investigación en Recursos Cinegéticos, Apdo. 535, E-13080, Ciudad Real, Spain, and Estación Biológica de Doñana, Apdo. 1056, E-41080 Sevilla, Spain

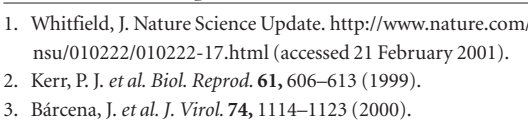

\section{Gulf syndrome research has passed peer review}

Sir - Your News report (Nature 410, 135; 2001) mentioned the negative comments made by a former US Department of Defense (DoD) employee, Bernard Rostker, and by Philip Landrigan, a Clinton committee appointee, about our published research on Gulf War syndrome. Because your story stated that our work was supported by a private foundation and non-peer-reviewed grant funds, and involved small patient samples, readers might be left with the impression that our findings are invalid.

This is not true. Over the past four years we have published 12 papers in prominent scientific journals establishing that there is a new syndrome with three variants in Gulf War veterans of a naval reserve battalion (see, for example, ref. 1). Our study of 63 cases and 186 controls identified strong associations with risk factors for exposure to sarin nerve gas and related chemicals. We have also identified affected brain regions and a genetic predisposition using a variety of techniques. Our design and sample sizes are equivalent to those used by the Centers for Disease Control and Prevention in such classic epidemic investigations as toxic shock syndrome, Four-Corners hantavirus pneumonia and AIDS.

The funding proposals for all our studies were rejected by the DoD's peerreview system but were funded by a private foundation or after appeal to higher government levels. Our results later passed rigorous peer review before publication in respected scientific journals. A consistent publishing record is a better indicator of scientific merit than the sources of funding, particularly in the politically charged environment of Gulf War research.

Robert W. Haley

University of Texas Southwestern Medical Center,

5323 Harry Hines Blvd, Dallas, Texas

75390-8874, USA

1. Haley, R. W. et al. Arch. Neurol. 57, 1280-1285 (2000). 